\title{
Genotypic and phenotypic similarity of multiresistant Acinetobacter baumannii isolates in the Czech Republic
}

\author{
A. NEMEC, L. JANDA*, O. MELTER and LENIE DIJKSHOORN $\dagger$ \\ National Institute of Public Health, Šrobárova 48, 10042 Prague 10, *Institute of Microbiology, Academy of \\ Sciences of the Czech Republic, Prague, Czech Republic and $\uparrow$ Department of Medical Microbiology, Leiden \\ University Medical Centre, Leiden, The Netherlands
}

\begin{abstract}
The diversity of 103 clinical isolates of the Acinetobacter calcoaceticus-Acinetobacter baumannii complex obtained between 1991 and 1997 from 17 Czech hospitals was studied by ribotyping, biotyping, plasmid profiling and antibiotic susceptibility testing. According to the EcoRI ribotypes, all but one of these isolates were identified to the DNA group level: 77 isolates were allocated to DNA group 2 ( $A$. baumannii), 14 to DNA group 3, 10 to DNA group 13 sensu Tjernberg and Ursing and one to DNA group 1 ( $A$. calcoaceticus). In total, 50 different EcoRI ribotypes and 10 biotypes were observed. Plasmids were found in $92 \%$ of the isolates and a high variability in plasmid profiles was found in isolates of the same DNA group. The combination of typing profiles allowed two predominant groups (termed $A$ and $B$ ) to be distinguished among the $A$. baumannii isolates ( 37 and eight isolates, respectively) that shared a specific ribotype and were highly similar in other properties. These two groups comprised both sporadic and outbreak isolates and were found in most localities. Group A and B isolates were markedly more resistant to antibiotics than most of the remaining isolates, thus representing $85 \%$ of all multiresistant isolates. The features of groups $A$ and $B$ corresponded to those of two epidemic clones identified recently among hospital strains in north-western Europe.
\end{abstract}

\section{Introduction}

During the last decades, bacteria of the genus Acinetobacter have emerged as important nosocomial pathogens. These micro-organisms can cause a wide range of clinical disorders, including pneumonia [1, 2], bacteraemia [2,3], burn infections [4] and urinary tract infections [5], particularly in severely ill, hospitalised patients. Numerous outbreaks of nosocomial infections with Acinetobacter spp. have been reported and these are often associated with the spread of multiresistant strains $[1,3,5-8]$. The genus is taxonomically heterogeneous and, by DNA-DNA hybridisation, 21 DNA groups have been described, seven of which have species rank [9-12]. DNA group 1 (A. calcoaceticus), DNA group 2 ( $A$. baumannii) and the unnamed DNA groups 3 and 13 sensu Tjernberg and Ursing are closely related genetically and very similar phenotypi-

Received 21 May 1998; accepted 13 July 1998.

Corresponding author: Dr A. Nemec. cally [13]. Therefore, it has been proposed to classify these groups together in the ' $A$. calcoaceticus $-A$. baumannii (Acb) complex' [13]. A. baumannii is the species isolated most frequently from clinical specimens, but strains of the other members of the $A c b$ complex are common in patient specimens and are also isolated during hospital outbreaks $[2,12,14,15]$. Phenotypic identification of the DNA groups included in the $A c b$ complex has been shown to be of doubtful value [13] and therefore species identity is not certain in studies that use only phenotypic tests. However, several genotypic methods have now been described that enable accurate differentiation between genomic groups of the $A c b$ complex [16-18].

Many recent studies on nosocomial Acinetobacter isolates have focused on either an evaluation of various typing methods or on an epidemiological investigation of hospital outbreaks. Most of these studies dealt with geographically limited collections of strains, i.e., isolated in one hospital or several hospitals located close to each other. Results obtained in different laboratories are difficult to compare 
because of variations in the methods used. However, a different strategy was followed in one study in that the various characteristics of $A$. baumannii strains from geographically distant localities of north-western Europe were compared [19]. With a combination of typing methods it was shown that most outbreak strains belonged to two distinct groups (clones), whereas sporadic strains were more heterogeneous.

The aim of the present study was to analyse the diversity of clinical isolates belonging to the $A c b$ complex collected over a period of several years from different Czech hospitals. A combination of genotypic and phenotypic methods was applied to identify the organisms to DNA group and strain level. These methods have been used repeatedly for the characterisation of acinetobacters $[12,15,19]$ and allowed the results to be compared with those of other studies.

\section{Materials and methods}

\section{Strains}

From 1991 to $1997, c .400$ clinical isolates belonging to the $A c b$ complex were received by the National Institute of Public Health from different diagnostic laboratories in the Czech Republic. In total, 103 isolates were selected from these 400 isolates. The selected isolates were from hospitalised patients only and differed as widely as possible in place and time of isolation. They originated from 40 different services of 17 hospitals in 14 Czech cities (Fig. 1; Table 1 [20]). Seven isolates representative of different groups of epidemiologically and genetically related isolates, i.e., those collected during incidents of epidemic spread and indistinguishable by typing (HindIII restriction analysis of whole-cell DNA and biotyping), were included in this collection. The isolates were from various clinical specimens, including sputum and tracheal aspirate (33 isolates), wound swabs (23), urine (22), drainage fluid (7), blood (7), intravenous catheters (6), nasopharyngeal swabs (4) and bile (1). The following strains were used as reference strains for different DNA groups of the Acb complex: ATCC strain 17902 (A. calcoaceticus), ATCC strain 19606 (A. baumannii), ATCC strain 19004 (DNA group 3) and ATCC strain 17903 (DNA group 13 sensu Tjernberg and Ursing (TU)); in addition, strains 5804 ('close to TU13') and 10169 ('between DNA groups 1 and 3') were kindly provided by $\mathrm{P}$. Gerner-Smidt, Statens Seruminstitut, Copenhagen, Denmark. Strains RUH 875 and RUH 134 represented two epidemic clones of $A$. baumannii recognised recently [19].

\section{Phenotypic identification}

All isolates had the basic properties of the genus Acinetobacter [21], i.e., gram-negative, strictly aerobic, oxidase-negative, non-motile coccobacilli. The isolates were placed in the $A c b$ complex on the basis of the biochemical tests suggested by Bouvet and Grimont [20], including growth in brain heart infusion broth at $37^{\circ}, 41^{\circ}$ and $44^{\circ} \mathrm{C}$, aerobic production of acid from glucose in $\mathrm{O} / \mathrm{F}$ medium, gelatine hydrolysis and utilisation of 14 different carbon sources. Carbon source utilisation was tested on agar plates containing the defined medium of Cruze et al. [22] supplemented with substrate $0.1 \% \mathrm{w} / \mathrm{v}$. Each plate was inoculated with a drop of cell suspension in saline prepared from an overnight culture and incubated at $30^{\circ} \mathrm{C}$ for 6 days. Utilisation of substrates was evaluated by comparing growth on supplemented plates with that on the control plate containing the mineral base only, with growth of even isolated colonies in the inoculum zone being considered positive.

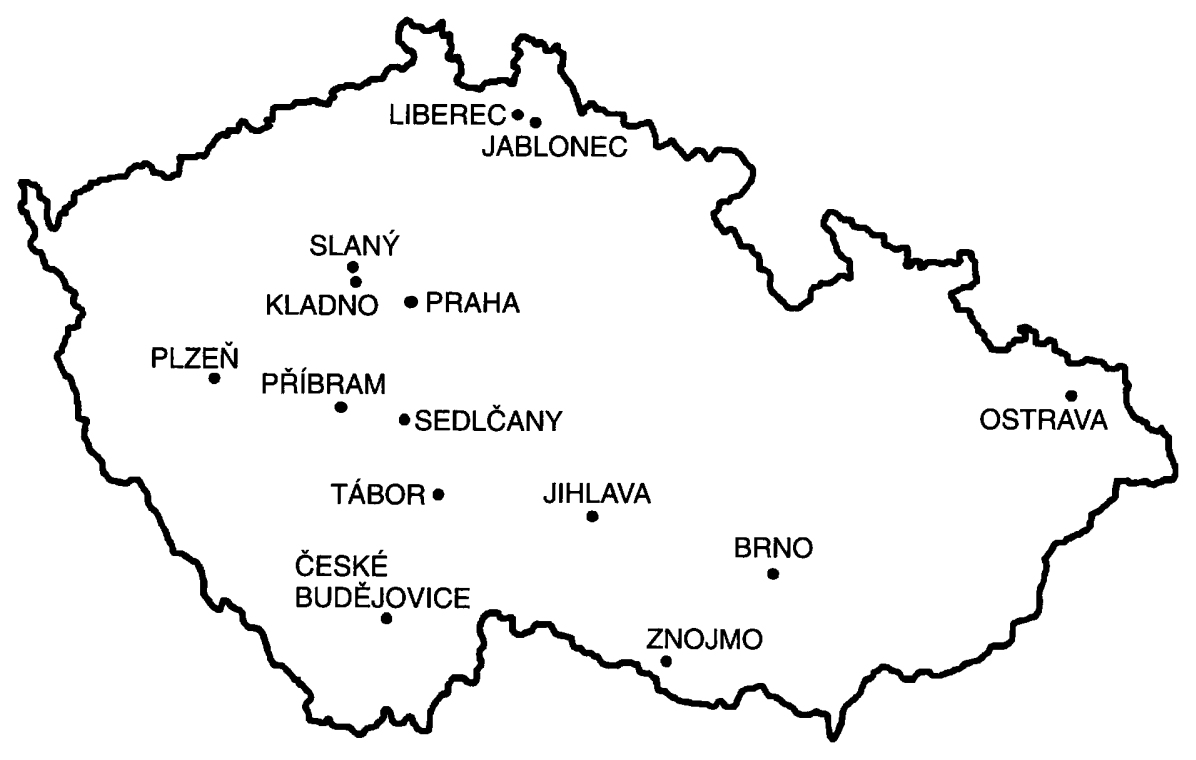

Fig. 1. Geographical location of hospitals in the Czech Republic from which the isolates belonging to the A. calcoaceticus $-A$. baumannii complex originated. 


\section{Biotyping}

Biotyping was based on utilisation of levulinate, citraconate, L-phenylalanine, phenylacetate, 4-hydroxybenzoate and L-tartrate [20].

\section{Antibiotic susceptibility testing}

Antimicrobial susceptibilities were determined by a disk diffusion method on Mueller-Hinton Agar (Oxoid). The antimicrobial agents tested $(\mu \mathrm{g} /$ disk) were: ampicillin + sulbactam $(10+10)$; ticarcillin $(75)$; ceftazidime (30); imipenem (10); gentamicin (10); tobramycin (10); amikacin (30); ofloxacin (5); and co-trimoxazole (sulphamethoxazole + trimethoprim: $23.75+1.25$ ) (Oxoid). The isolates were classified as susceptible, intermediate or resistant according to the recommendations of the National Committee for Clinical Laboratory Standards [23].

\section{Ribotyping}

Whole-cell DNA was prepared by the method of Grimberg et al. [24], with minor modifications. Briefly, $1 \mathrm{ml}$ of nutrient broth culture grown overnight at $30^{\circ} \mathrm{C}$ was harvested by centrifugation and the pellet was washed with $1 \mathrm{ml}$ of TNE (10 mM Tris- $\mathrm{HCl}, 10 \mathrm{mM}$ EDTA, $10 \mathrm{mM} \mathrm{NaCl}, \mathrm{pH} 8.0$ ) and resuspended in $150 \mu \mathrm{l}$ of the same buffer. Then $150 \mu \mathrm{l}$ of TNE containing Triton X-100 $2 \% \mathrm{v} / \mathrm{v}$ and lysozyme (final concentration $5 \mathrm{mg} / \mathrm{ml}$; Serva, Heidelberg, Germany) was added and the suspension was incubated at $37^{\circ} \mathrm{C}$ for $20 \mathrm{~min}$. Proteinase $\mathrm{K}$ (final concentration $1 \mathrm{mg} / \mathrm{ml}$; Serva) was added to the lysed bacterial cell suspension and incubation was continued for $2 \mathrm{~h}$ at $65^{\circ} \mathrm{C}$. Restriction endonuclease digestion of DNA samples was performed for $3 \mathrm{~h}$ at $37^{\circ} \mathrm{C}$ with $20 \mathrm{U}$ of EcoRI (Fermentas, Vilnius, Lithuania) in $25 \mu$ l of incubation buffer supplied by the enzyme manufacturer. Electrophoretic separation of DNA fragments was done in agarose $0.7 \% \mathrm{w} / \mathrm{v}$ gels in TBE buffer ( $45 \mathrm{mM}$ Trisborate, $1 \mathrm{mM}$ EDTA, pH 8.0). Phage $\lambda$ DNA (Fermentas) digested with HindIII and StyI (Fermentas) was used as molecular size markers. DNA fragments were transferred on to Zeta-Probe nylon membranes (BioRad) with a vacuum blotter (BioRad) and $10 \times \mathrm{SSC}$ $(1.5 \mathrm{M} \mathrm{NaCl}, 0.15 \mathrm{M}$ sodium citrate, $\mathrm{pH} 7.0$ ) as the transfer solution. A $16 \mathrm{~S}$ and $23 \mathrm{~S} E$. coli rRNA (Boehringer) probe was labelled with digoxigenin-11dUTP by M-MuLV reverse transcriptase (Boehringer) and random priming in accordance with the instructions given in the DIG DNA Labelling and Detection Non-Radioactive Applications Manual (Boehringer). The labelled probe used for detection of the molecular markers was obtained by random priming of phage $\lambda$ DNA with digoxigenin-11-dUTP and a DIG DNA Labelling Kit (Boehringer). Pre-hybridisation, hybridisation (at $65^{\circ} \mathrm{C}$ ) and washes were done as specified in the Zeta-Probe Blotting Membranes Instruction Manual (BioRad). Immunodetection of hybridised DNA was performed with a DIG Nucleic Acid Detection Kit
(Boehringer). Identification to the DNA group level was performed by visual comparison of the patterns with those of a set of reference patterns as described by Gerner-Smidt [16]. Similar ribotypes were compared in adjacent lanes on the same gel; they were considered different even if there was a difference in the position of only one band.

\section{Plasmid analysis}

To isolate plasmid DNA, the method of Kado and Liu [25] was modified as follows. Pelleted cells from $0.6 \mathrm{ml}$ of an overnight culture were resuspended in $1 \mathrm{ml}$ of saline and $26 \mu \mathrm{l}$ of N-tetradecyl-N,N-dimethyl3-ammonio-1-propanesulphonate (Boehringer) $1 \% \mathrm{w} / \mathrm{v}$ in $100 \mathrm{mM}$ citric acid were added. After incubation at $37^{\circ} \mathrm{C}$ for $10 \mathrm{~min}$, cells were pelleted and resuspended in $0.15 \mathrm{ml}$ of TE buffer (10 mM Tris. $\mathrm{HCl}, 1 \mathrm{mM}$ EDTA, $\mathrm{pH}$ 8.0). To this was added $300 \mu \mathrm{l}$ of lysing solution (SDS $3 \% \mathrm{w} / \mathrm{v}, 50 \mathrm{mM}$ Tris, $32 \mathrm{mM} \mathrm{NaOH}$ ) and the mixture was incubated for up to $15 \mathrm{~min}$ at $37^{\circ} \mathrm{C}$. The lysed bacterial suspension was extracted once with $0.9 \mathrm{ml}$ of water unsaturated phenol:chloroform (1:1), and the aqueous phase was incubated with RNase A (Sigma) $20 \mu \mathrm{g} / \mathrm{ml}$ at $37^{\circ} \mathrm{C}$ for $30 \mathrm{~min}$. The DNA was electrophoresed on agarose $0.7 \% \mathrm{w} / \mathrm{v}$ gels in TAE buffer ( $40 \mathrm{mM}$ Tris-acetate, $1 \mathrm{mM}$ EDTA, pH 8.0), stained with ethidium bromide and photographed under UV light. Supercoiled DNA ladder (D-5292; Sigma) was used to provide molecular markers. For restriction endonuclease digestion, aqueous DNA solution was purified of phenol by extraction with diethylether, precipitated with $800 \mu \mathrm{l}$ of ethanol and dissolved in $30 \mu \mathrm{l}$ of TE buffer. To verify the structural identity of $8.7-\mathrm{kb}$ plasmids that were found frequently in $A$. baumannii isolates, a digoxigenin-labelled probe was prepared from one of these plasmids. The plasmid was extracted from isolate no. 632 which did not contain any other plasmids, purified in a caesium chloride gradient [26], and labelled by random priming with digoxigenin-11-dUTP and a DIG DNA labelling kit. Plasmid or whole-cell DNA digested with HindIII (Fermentas) was transferred on to a nylon membrane and hybridised with the probe. All steps for restriction endonuclease digestion, vacuum-transfer, hybridisation and detection were performed as described for ribotyping (see above).

\section{Results}

\section{Identification}

The properties and epidemiological data of the 103 isolates studied are given in Table 1. According to their EcoRI ribotypes, 77 isolates were allocated to DNA group 2, 14 isolates to DNA group 3, 10 isolates to DNA group 13TU and one isolate to DNA group 1 . Isolate no. 417 could not be allocated unambiguously to any of these DNA groups. The pattern of isolate no. 417 had bands in common with both DNA group 2 and 


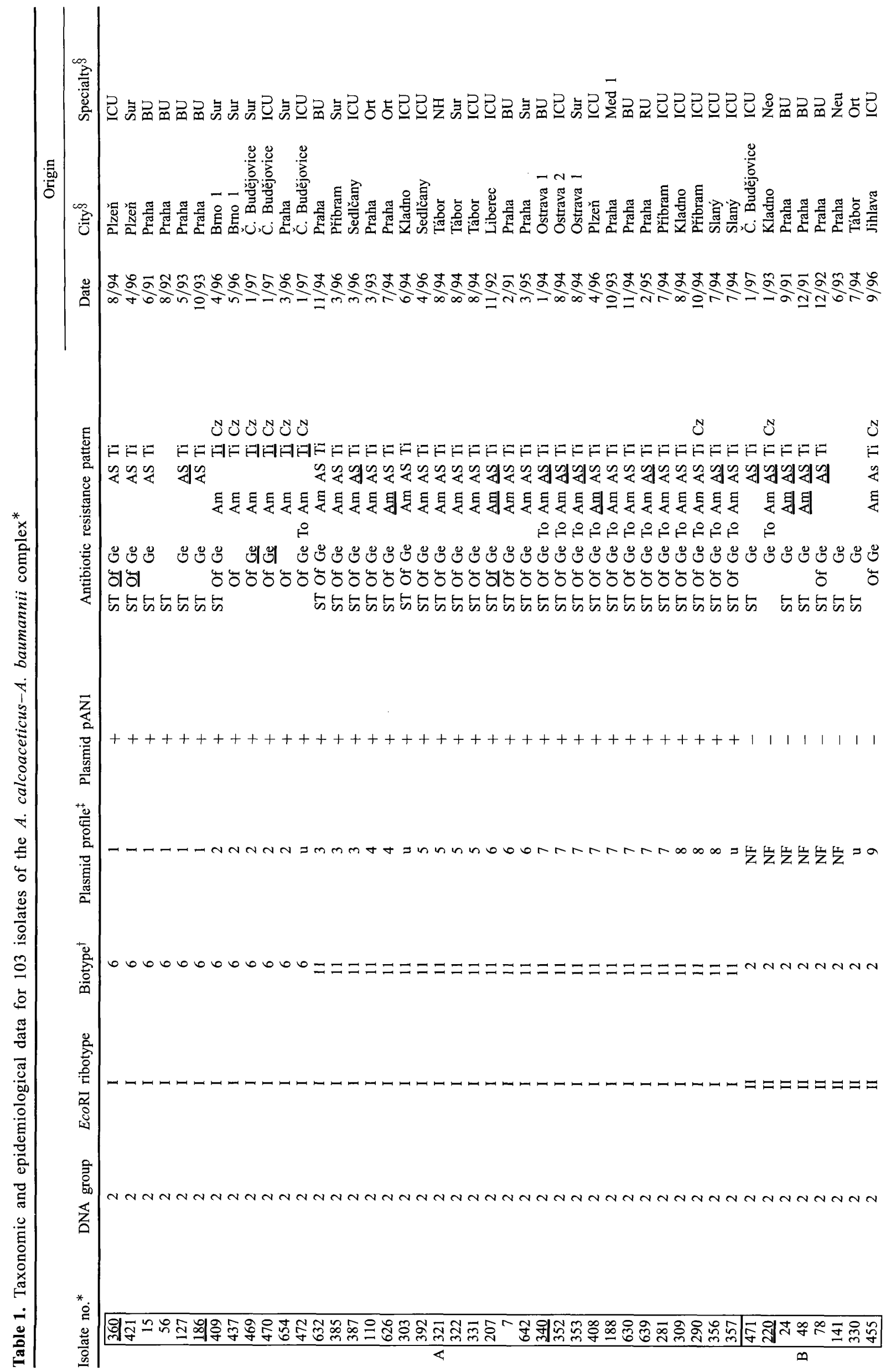




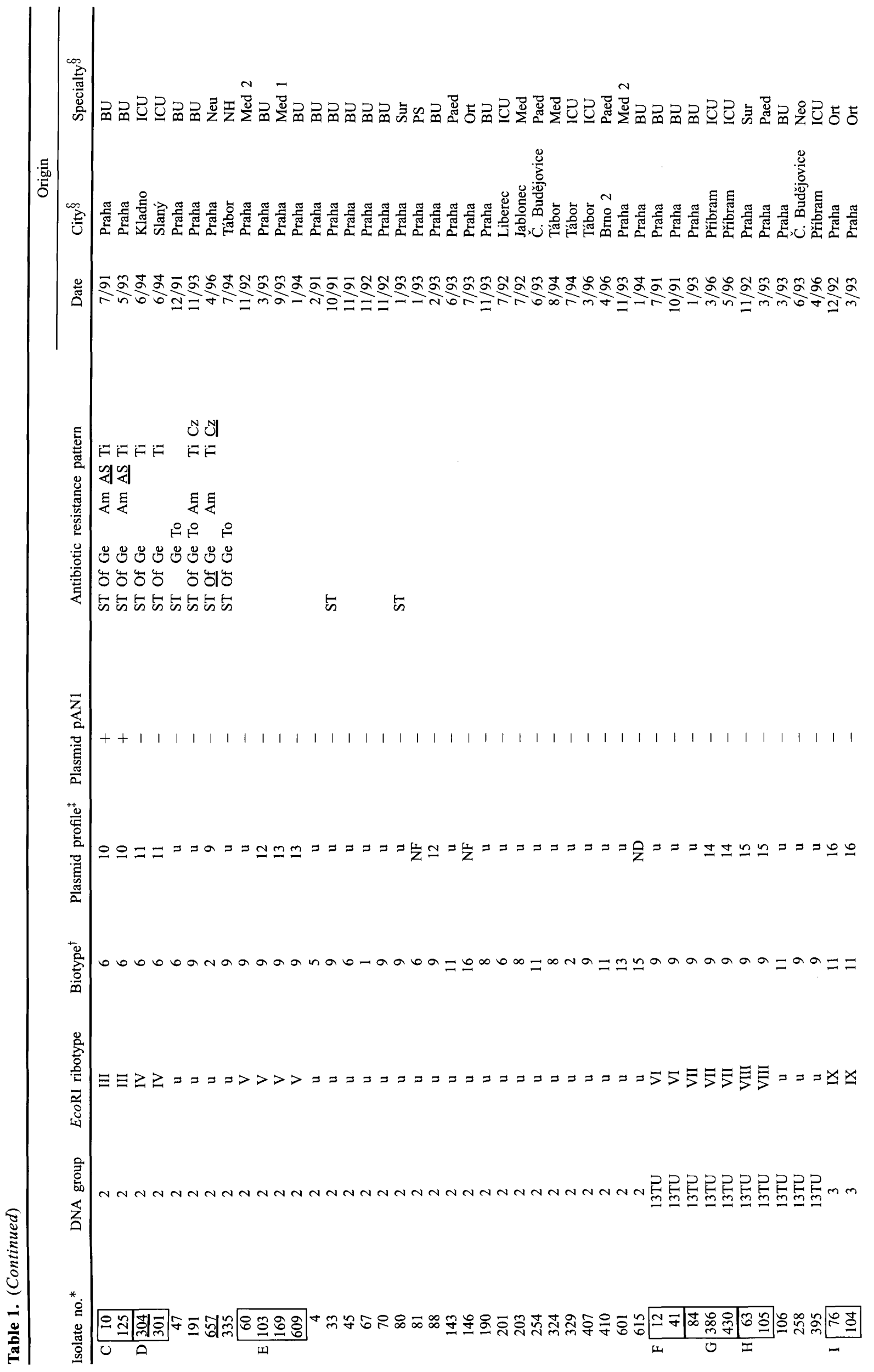




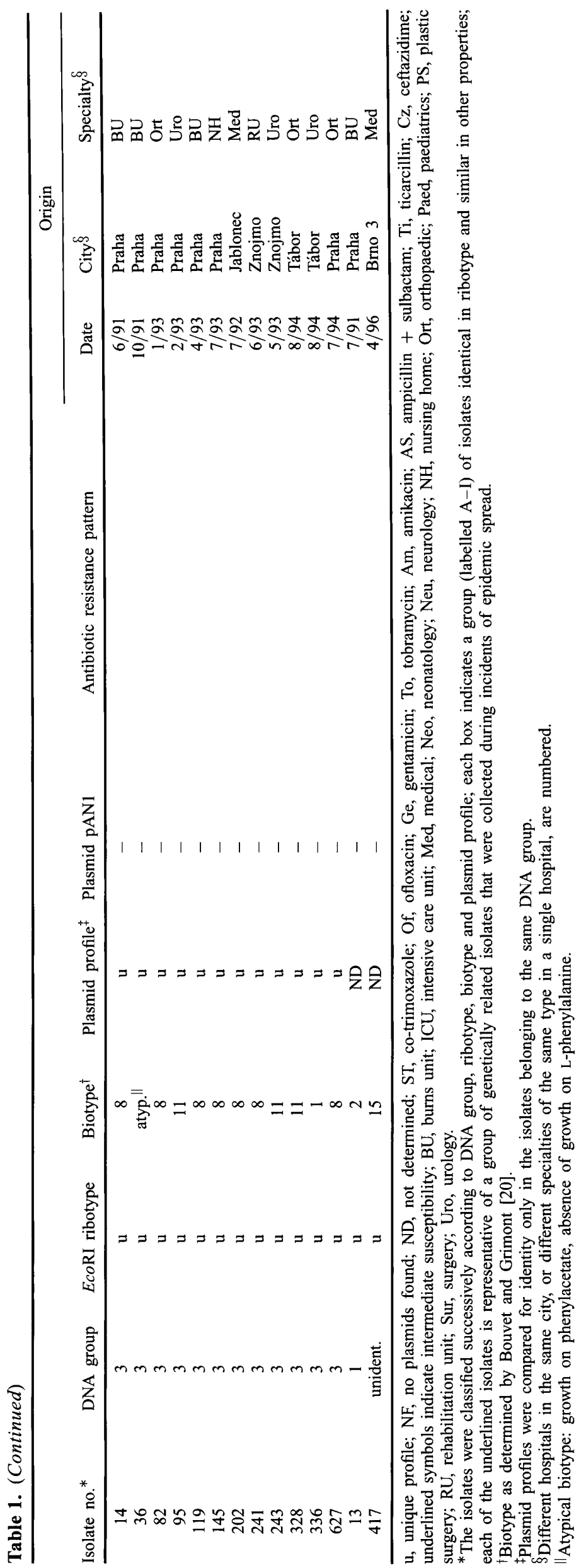


DNA group 13TU, but some other bands of these DNA groups were missing in this isolate (Fig. 2). When compared with the reference strains of two additional DNA groups, several common bands with strain no. 5804 ('close to TU13') were found (data not shown). All isolates identified as A. baumannii or DNA group $13 \mathrm{TU}$ showed growth at $44^{\circ} \mathrm{C}$, whereas all isolates identified as DNA group 3 and isolate no. 417 grew at $41^{\circ} \mathrm{C}$, but not at $44^{\circ} \mathrm{C}$. The single isolate identified as A. calcoaceticus grew at $37^{\circ} \mathrm{C}$ only.

\section{Ribotypes}

Twenty-nine different EcoRI ribotypes were observed among the isolates of $A$. baumannii (Table 1). Ribotypes I and II were found in 37 and eight isolates, respectively, representing together as many as $58 \%$ of all $A$. baumannii isolates. Ribotype $\mathrm{V}$ was revealed in four isolates, ribotypes III and IV were each shared by two isolates, and 24 ribotypes were found only once. Isolates of DNA group 13TU showed six different ribotypes, with ribotypes VI, VII and VIII represented by two, three and two isolates, respectively, with three ribotypes represented by only one isolate. DNA group 3 isolates showed the highest heterogeneity, as only one of 13 different ribotypes observed was found in two isolates, while the other profiles were recorded only once.

\section{Biotypes}

Biotyping according to Bouvet and Grimont allowed 10 biotypes to be distinguished. $A$. baumannii isolates belonged to biotypes $1,2,5,6,8,9,11,13,15$ and 16 . Biotype 11 was the most frequent ( 28 isolates), followed by biotypes 6,9 and $2(20,11$ and 10 isolates respectively). Biotypes 1,8 and 11 were encountered among the isolates of DNA group 3, with biotype 8 being predominant (seven isolates). Isolate no. 36 appeared atypical as it grew on phenylacetate but not on L-phenylalanine. Isolates of DNA group $13 \mathrm{TU}$ belonged to biotype 9, except for isolate no. 106 which was of biotype 11 . The single $A$. calcoaceticus isolate belonged to biotype 2, while isolate no. 417 was of biotype 15 .

\section{Antibiograms}

All isolates were susceptible to imipenem and, according to their susceptibility to the other antibiotics, could be divided into two main groups. The 'susceptible' group included 48 isolates susceptible to all antibiotics, i.e., $22 \mathrm{~A}$. baumannii isolates and all non- $A$. baumannii isolates. The 'resistant' group included $52 \mathrm{~A}$. baumannii isolates resistant to two or more antibiotics, including at least one of the aminoglycosides. The remaining three $A$. baumannii isolates were resistant only to co-trimoxazole.

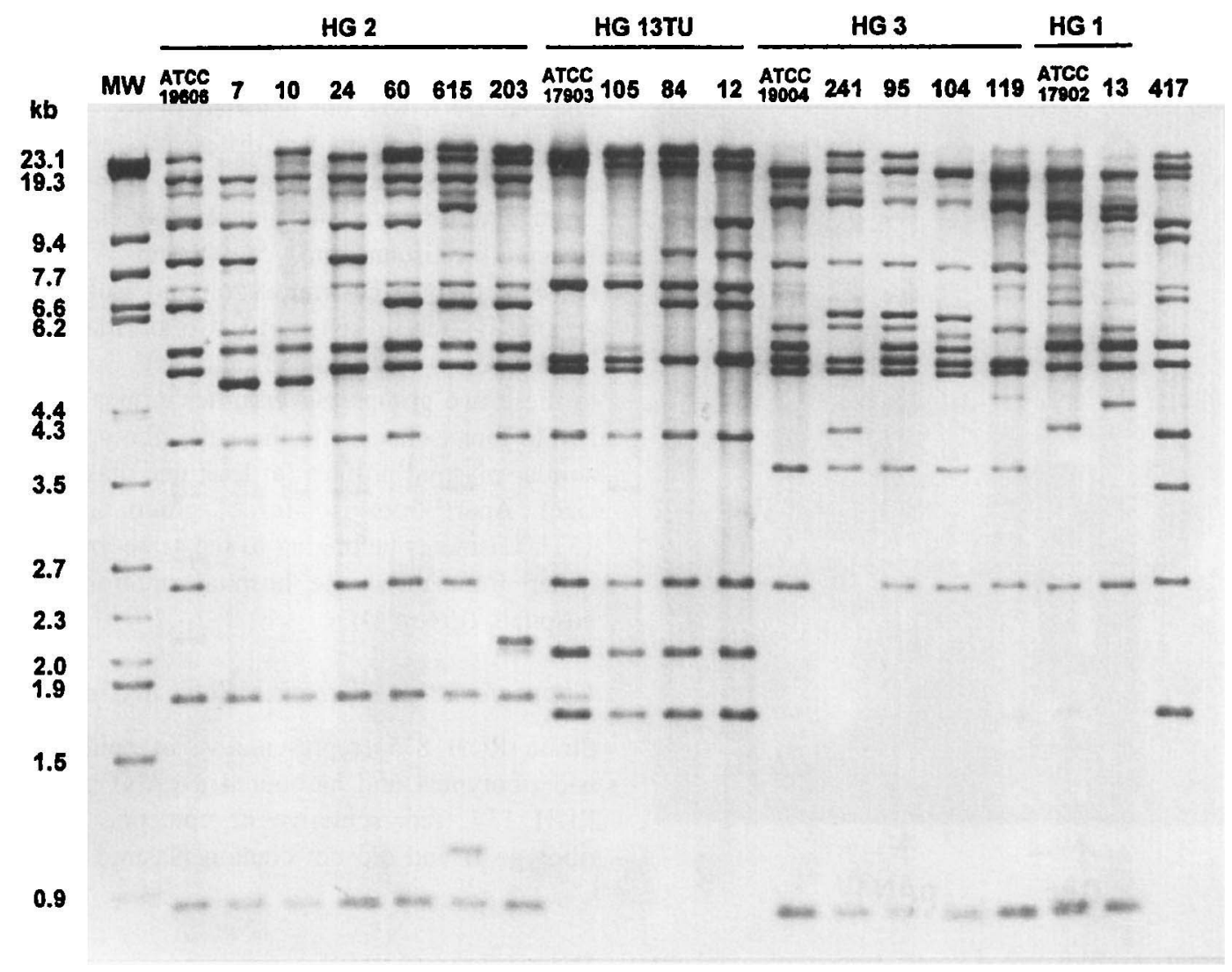

Fig. 2. Examples of EcoRI ribotypes showing those for 15 clinical isolates and four reference strains of the $A$. calcoaceticus $-A$. baumannii complex. Isolate nos 7 and 24 represent groups A and B (Table 1), respectively; isolate no. 417, ungrouped; HG, hybridisation (DNA) group; MW, mol. wt markers (phage $\lambda$ DNA digested with HindIII and Sty I). 


\section{Plasmid analysis}

Plasmids were detected in all isolates of DNA groups 3 and 13TU, and in $68(89 \%)$ of $76 \mathrm{~A}$. baumannii isolates, ranging in size between $2 \mathrm{~kb}$ and $>100 \mathrm{~kb}$. Plasmid profiles contained one to six bands and were compared for similarity only in the isolates belonging to the same DNA group. In total, 37, eight and 13 different profiles were found among the isolates of DNA groups 2, 13TU and 3, respectively. Some different profiles shared one or more plasmids of similar size. These profiles were observed mostly in isolates with an identical ribotype. Each of the ribotype I isolates carried a plasmid of c. $8.7 \mathrm{~kb}$ (Fig. 3). Plasmids of this size were not found in any of the other isolates, except for two isolates with ribotype III. As isolates with ribotypes I and III mostly carried one to four additional plasmids, the structural similarity of the

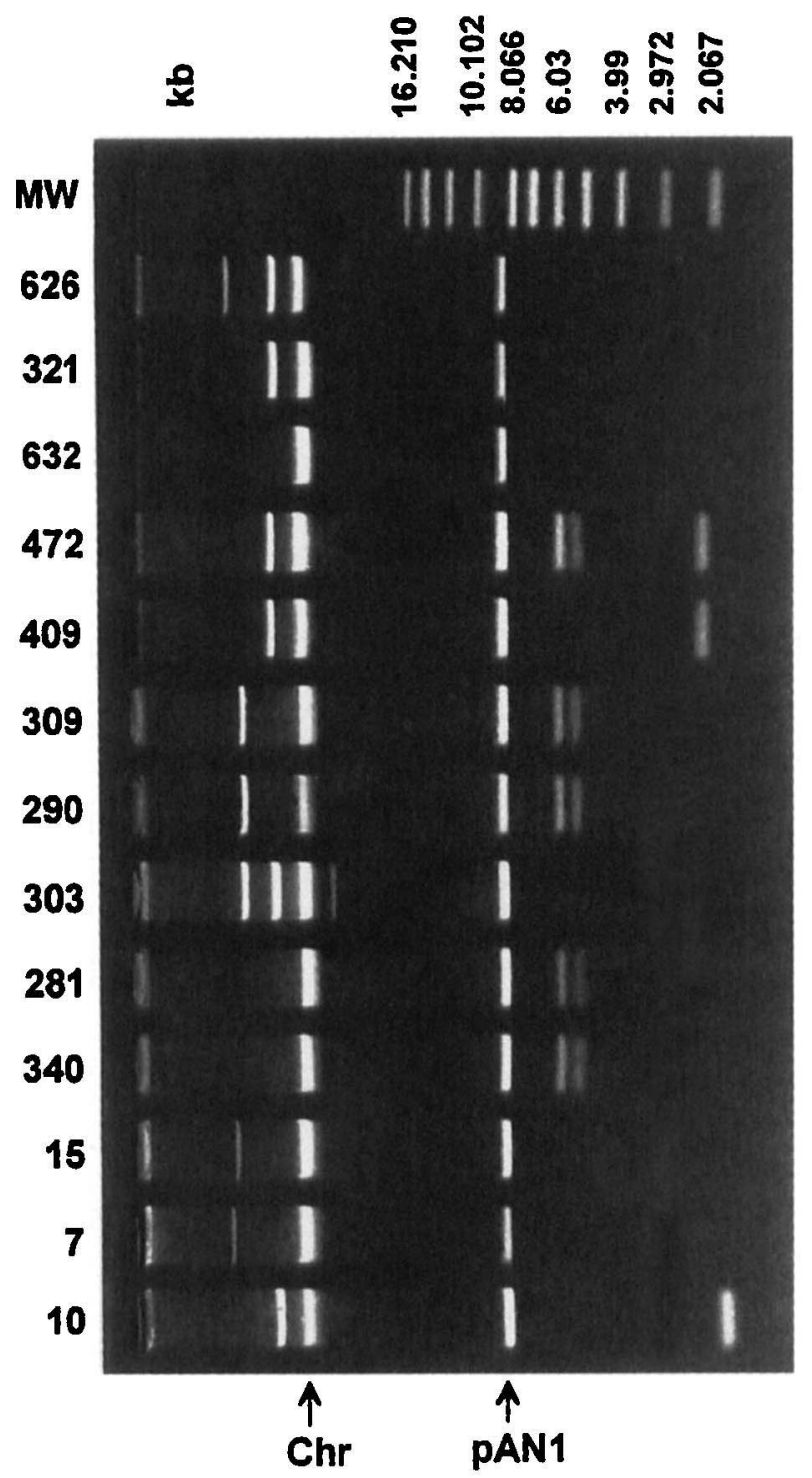

Fig. 3. Plasmid profiles of $13 \mathrm{~A}$. baumannii isolates characterised by the presence of an $8.7-\mathrm{kb}$ plasmid (pAN1). Except for isolate no. 10, all belonged to the most prevalent EcoRI ribotype. MW, mol. wt marker (supercoiled DNA ladder, Sigma D-5292); Chr, chromosomal DNA. 8.7-kb plasmids was investigated by hybridisation of HindIII restriction profiles of plasmid DNA with a probe made from the $8.7-\mathrm{kb}$ plasmid (designated pAN1) from isolate no. 632. In each case, three fragments were detected, $4.8,2.6$ and $1.3 \mathrm{~kb}$ in size, corresponding to the HindIII restriction profile of purified plasmid pAN1 DNA. The presence of sequences homologous with pAN1 in the remaining isolates of the $A c b$ complex was investigated by hybridisation of the pAN1 probe with HindIII restriction profiles of whole-cell DNA. No positive signal was recorded for 59 isolates, while five isolates yielded one band each of varying sizes (data not shown). The localisation of these sequences (i.e., on plasmid or chromosome) was not studied.

\section{Correlation between the ribotypes and other characteristics}

The combination of typing profiles allowed nine groups of isolates to be defined (labelled $\mathrm{A}-\mathrm{I}$ ) that shared a specific ribotype and were highly similar in other properties (Table 1). Group A included $37 \mathrm{~A}$. baumannii isolates with ribotype $\mathrm{I}$ that belonged to biotypes 11 and 6 ( 25 and 12 isolates respectively). Moreover, all isolates of this group contained a pAN1 plasmid. The group A isolates originated from 22 hospital specialties in 11 cities. Isolates impossible to differentiate by any of the methods used came from the same locality and also from geographically distant hospitals. Group B included eight $A$. baumannii isolates with ribotype II that belonged to biotype 2 . Plasmid DNA was not detected in six isolates of this group, while a plasmid of different size was present in each of two other isolates. The group B isolates originated from six hospital specialties in five cities. Except for isolate no. 56 (group A), which was resistant only to co-trimoxazole, all isolates in groups $\mathrm{A}$ and $\mathrm{B}$ were resistant to two or more antibiotics. Therefore, $44(85 \%)$ of 52 'resistant' isolates belonged to these two groups. Seven other groups each included two to four isolates with the same ribotype, biotype and similar plasmid profiles (at least one plasmid of similar size). Apart from isolates of group G (DNA group $13 T U$ ), isolates belonging to the same group originated either from the same hospital or from two nearby hospitals (group D).

\section{Characteristics of strains RUH 875 and RUH 134}

Strain RUH 875 (representative of epidemic clone I) had ribotype I and harboured a pAN1 plasmid; strain RUH 134 (representative of epidemic clone II) had ribotype II and did not contain plasmid DNA.

\section{Discussion}

In this study, $A$. baumannii was the most frequent group among isolates of the $A c b$ complex. All multiresistant and outbreak isolates belonged to this species. 
These findings are consistent with previous studies $[14,17,20]$ and corroborate findings of the major epidemiological and clinical importance of $A$. baumannii among the other nomenspecies and DNA groups of Acinetobacter. DNA group 3, also isolated frequently from hospital patients and found to be associated with hospital outbreaks $[2,15]$, was the second most numerous group. The fact that $10 \%$ of the isolates belonged to DNA group 13TU, not included in the Bouvet and Grimont scheme $[9,20]$, is indicative of the importance of this group.

Ribotyping allows both species identification and the detection of genetic relatedness between strains at the subspecies level [27]. Previous studies have shown a wide diversity of $E_{c o}$ RI ribotypes in the $A c b$ complex and this finding proved useful for typing hospital isolates [16, 28, 29]. The diversity in EcoRI ribotypes among DNA group 3 isolates, was confirmed, with most of these isolates having a unique ribotype. $A$. baumannii was different in that $>50 \%$ of the isolates belonged only to two ribotypes. The isolates with identical ribotypes were also similar in other characteristics such as plasmid profile, biotype and susceptibility to antimicrobial agents. Such a correspondence of genotypic and phenotypic characteristics can be explained by a common clonal origin [30]. Therefore, the two most numerous groups of isolates, $\mathrm{A}$ and $\mathrm{B}$, seem to represent two evolutionary lineages of $A$. baumannii dispersed widely in hospitals throughout the Czech Republic.

A separate recent study [19] compared the genotypic and phenotypic properties of outbreak and sporadic $A$. baumannii strains from different north-western European cities and found that most outbreak strains could be placed in two similarity groups (designated as clones I and II), whereas sporadic strains were more heterogeneous. Strain RUH 875 (representative of clone I) was identical in ribotype with group $\mathrm{A}$ in the present study, while strain RUH 134 (representative of clone II) was identical in ribotype with group B. Strains of clone I belonged to biotypes 6,11 and 19 , while isolates of group A belonged to biotypes 6 and 11. Similarly, strains of clone II belonged to biotypes 1,2 and 9 , while isolates of group B belonged to biotype 2 . Both clones I and II, and groups A and B were characterised by a higher degree of resistance to antibiotics compared with most of the other strains. In addition, the cryptic plasmid pAN1, characteristic of the group A isolates, was also detected in strain RUH 875, while no plasmid was found in either strain RUH 134 or most group B isolates. Thus, the north-western European clones corresponded with the two Czech groups in their genotypic and phenotypic characteristics.

Previous studies have pointed out the predominant frequency of certain biotypes amongst $A$. baumannii isolates, namely biotypes $1,2,6$ and $9[14,20]$. The most frequent biotype in the present study was biotype
11, found rather rarely in other studies. When comparing the properties of the $A$. baumannii isolates belonging to the same biotype, the frequent biotypes 6 and 9 were found to comprise genotypically heterogeneous isolates. In contrast, except for a few cases, isolates of biotype 11 had indistinguishable ribotypes, i.e., belonged to group $\mathrm{A}$. Therefore, the frequent occurrence of biotype 11 in the Czech Republic is the result of its predominance among the strains of a highly prevalent clonal group.

A high frequency of genetically related strains among the outbreak and multiresistant strains may affect the efficacy of some typing methods used in epidemiological investigations of acinetobacter infections, i.e., in the case of the concurrent spread of different strains of the same clone. Some electrophoretic methods, such as ribotyping with $E c o$ RI or cell envelope protein analysis, are apparently not useful for subtyping these strains [19], and the efficacy of other methods remains to be evaluated. Of these methods, macro-restriction analysis has been shown to be more discriminatory than ribotyping in $A$. baumannii [31] and may prove useful in this context. Moreover, the variations that were found in plasmid profiles and biotypes may also be of use in the further differentiation of isolates of the most prevalent Czech group.

In summary, almost half the Czech hospital isolates of the $A c b$ complex fell into two groups of $A$. baumannii, highly similar to two clones which have been reported to predominate among the outbreak strains of north-western Europe. These groups comprised both outbreak and sporadic strains isolated within the last 7 years from all over the Czech Republic. Moreover, isolates of these groups were much more resistant to antibiotics than the remaining isolates. The finding that the multiresistance is linked to a limited range of genetically related strains is surprising and may be significant in the light of the progressive increase in resistance in Acinetobacter strains during the last decades.

We thank E. Mohelská for her excellent technical assistance and E. Kodytková for her valuable help in the preparation of the manuscript. This study was supported by research grant no. 3486-3 of the Internal Grant Agency of the Ministry of Health of the Czech Republic. Part of this work was presented as a poster at the 8th European Congress of Clinical Microbiology and Infectious Diseases, Lausanne, Switzerland, 1997 (P882).

\section{References}

1. Hartstein AI, Rashad AL, Liebler JM et al. Multiple intensive care unit outbreak of Acinetobacter calcoaceticus subspecies anitratus respiratory infection and colonization associated with contaminated, reusable ventilator circuits and resuscitation bags. Am J Med 1988; 85: 624-631.

2. Horrevorts A, Bergman K, Kollée L, Breuker I, Tjernberg I, Dijkshoorn L. Clinical and epidemiological investigations of Acinetobacter genomospecies 3 in a neonatal intensive care unit. J Clin Microbiol 1995; 33: 1567-1572.

3. Beck-Saugé CM, Jarvis WR, Brook JH et al. Epidemic 
bacteriemia due to Acinetobacter baumannii in five intensive care units. Am J Epidemiol 1990; 132: 723-733.

4. Green AR, Milling MAP. Infection with Acinetobacter in a burns unit. Burns Incl Therm Inf 1983; 9: 292-294.

5. Pedraza F, Andreu A, Saune M, Moreno A, Ramirez L, Garcia L. [A urinary outbreak of Acinetobacter baumannii in a spinal cord injury unit.] Ann Med Interne (Pan's) 1993; 10: 55-58.

6. Struelens MJ, Carlier E, Maes N, Serruys E, Quint WGV, van Belkum A. Nosocomial colonization and infection with multiresistant Acinetobacter baumannii: outbreak delineation using DNA macrorestriction analysis and PCR-fingerprinting. $J$ Hosp Infect 1993; 25: 15-32.

7. Bergogne-Bérézin E. The increasing significance of outbreaks of Acinetobacter spp.: the need for control and new agents. $J$ Hosp Infect 1995; 30 Suppl: 441-452.

8. Crowe M, Towner KJ, Humpreys $\mathrm{H}$. Clinical and epidemiological features of an outbreak of acinetobacter infection in an intensive therapy unit. $J$ Med Microbiol 1995; 43: 55-62.

9. Bouvet PJM, Grimont PAD. Taxonomy of the genus Acinetobacter with the recognition of Acinetobacter baumannii sp. nov., Acinetobacter haemolyticus sp. nov., Acinetobacter johnsonii sp. nov., and Acinetobacter junii sp. nov., and emended descriptions of Acinetobacter calcoaceticus and Acinetobacter lwoffii. Int J Syst Bacteriol 1986; 36: 228-240.

10. Tjernberg I, Ursing J. Clinical strains of Acinetobacter classified by DNA-DNA hybridization. APMIS 1989; 97: 595-605.

11. Bouvet PJM, Jeanjean S. Delineation of new proteolytic genomic species in the genus Acinetobacter. Res Microbio 1989; 140: 291-299.

12. Gerner-Smidt P, Tjernberg I. Acinetobacter in Denmark: II Molecular studies of Acinetobacter calcoaceticus-Acinetobacter baumannii complex. APMIS 1993; 101: 826-832.

13. Gerner-Smidt P, Tjernberg I, Ursing J. Reliability of phenotypic tests for identification of Acinetobacter species. $J$ Clin Microbiol 1991; 29: 277-282.

14. Seifert H, Schulze A, Baginski R, Pulverer G. The distribution of Acinetobacter species in clinical culture materials. Zbl Bakt Int $J$ Med Microbiol Virol Parasitol Infect Dis 1993; 279: 544-552.

15. Dijkshoorn L, Aucken HM, Gerner-Smidt P, Kaufmann ME Ursing J, Pitt TL. Correlation of typing methods for Aci netobacter isolates from hospital outbreaks. J Clin Microbiol 1993; 31: 702-705.

16. Gerner-Smidt P. Ribotyping of the Acinetobacter calcoaceticus-Acinetobacter baumannii complex. J Clin Microbiol 1992 30: $2680-2685$.

17. Dolzani L, Tonin E, Lagatolla C, Prandin L, Monti-Bragadin C. Identification of Acinetobacter isolates in the A. calcoaceticus-A. baumannii complex by restriction analysis of the 16S-23S rRNA intergenic spacer sequences. $J$ Clin Microbiol
1995; 33: 1108-1113.

18. Vaneechoutte M, Dijkshoorn L, Tjernberg I et al. Identification of Acinetobacter genomic species by amplified ribosomal DNA restriction analysis. $J$ Clin Microbiol 1995; 33: 11-15.

19. Dijkshoorn L, Aucken H, Gerner-Smidt $P$ et al. Comparison of outbreak and nonoutbreak Acinetobacter baumannii strains by genotypic and phenotypic methods. J Clin Microbiol 1996; 34: $1519-1525$.

20. Bouvet PJM, Grimont PAD. Identification and biotyping of clinical isolates of Acinetobacter. Ann Inst Pasteur/Microbiol 1987; 138: $569-578$.

21. Juni E. Genus III. Acinetobacter Brisou and Prévot 1954 $727^{\mathrm{AL}}$. In: Krieg NR, Holt JG (eds) Bergey's Manual of systematic bacteriology, vol 1. Baltimore, Williams and Wilkins. 1984: 303-307.

22. Cruze JA, Singer JT, Finnerty WR. Conditions for quantitative transformation in Acinetobacter calcoaceticus. Curr Microbiol 1979; 3: 129-132.

23. National Committee for Clinical Laboratory Standards. Performance standard for antimicrobial susceptibility testing. Sixth informational Supplement M100-S6. Villanova, PA, NCCLS. 1995

24. Grimberg J, Maguire S, Belluscio L. A simple method for the preparation of plasmid and chromosomal E. coli DNA. Nucleic Acids Res 1989; 17: 8893 .

25. Kado CI, Liu ST. Rapid procedure for detection and isolation of large and small plasmids. $J$ Bacteriol 1981; 145: 13651373.

26. Sambrook J, Fritsch EF, Maniatis T. Purification of closed circular DNA by equilibrium centrifugation in CsCl-ethidium bromide gradients. In: Molecular cloning: a laboratory manual, vol 1, 2nd edn. Cold Spring Harbor, NY, Cold Spring Harbor Laboratory Press. 1989: 1.42-1.43.

27. Stull TL, LiPuma JJ, Edlind TD. A broad-spectrum probe for molecular epidemiology of bacteria: ribosomal RNA. $J$ Infect Dis 1988; 157: 280-286

28. Ratto P, Sordelli DO, Abeleira E, Torrero M, Catalano M. Molecular typing of Acinetobacter baumanni-Acinetobacter calcoaceticus complex isolates from endemic and epidemic nosocomial infections. Epidemiol Infect 1995; 114: 123-132.

29. García-Arata MI, Gerner-Smidt P, Lópex-Brea M. Epidemiological study of Acinetobacter species isolated from an intensive care unit. APMIS 1997; 105: 131-138.

30. Ørskov F, Ørskov I. Summary of a workshop on the clone concept in epidemiology, taxonomy, and evolution of the Enterobacteriaceae and other bacteria. J Infect Dis 1983; 148: 346-357.

31. Seifert H, Gerner-Smidt P. Comparison of ribotyping and pulsed-field electrophoresis for molecular typing of Acinetobacter isolates. J Clin Microbiol 1995; 33: 1402-1407. 